\title{
Rubiacearum Americanarum Magna Hama Pars XLIII: New Species and Notes on South American Hippotis (Condamineae) and Schradera (Schradereae)
}

\author{
Charlotte M. Taylor \\ Missouri Botanical Garden, 4344 Shaw Blvd., St. Louis, Missouri 63110, U.S.A. \\ charlotte.taylor@mobot.org
}

David A. Neill

Universidad Estatal Amazónica, Paso lateral km 2 1/2 via a Napo, Puyo, Pastaza, Ecuador.

\section{Melissa Calderón Cruz}

Herbario del Departamento de Biología (UPRRP), Universidad de Puerto Rico-Recinto de Río Piedras, P.O. Box 23360, San Juan, Puerto Rico 00931-3360, U.S.A.

melissa.calderon23@yahoo.com

Abstract. This paper reviews Hippotis Ruiz \& Pav. and Schradera Vahl, two Rubiaceae genera with centers of diversity in western South America. Both are inadequately known and in need of field study. Recent authors' circumscriptions of $H$. albiflora $\mathrm{H}$. Karst. and $H$. mollis Standl. are narrowed here, and four new species of Hippotis are described: H. antioquiana C. M. Taylor from northwestern Colombia, H. ecuatoriana C. M. Taylor from central-southern Ecuador, H. elegantula C. M. Taylor \& M. Calderón from the western Amazon basin in Ecuador, and H. vasqueziana C. M. Taylor from lowland northeastern Peru. Four new species of Schradera Vahl are also described here: S. cernua C. M. Taylor and S. francoae C. M. Taylor from western Colombia, S. condorica C. M. Taylor \& D. A. Neill from southern Ecuador, and S. morindoides C. M. Taylor from southern Ecuador and northern Peru. Schradera condorica at least sometimes is a free-standing tree, a habit newly documented for this genus.

Key words: Colombia, Condamineae, Ecuador, Hippotis, Peru, Rubiaceae, Schradera, Schradereae.

Taxonomic review of two poorly known genera of Rubiaceae, Hippotis Ruiz \& Pav. and Schradera Vahl, clarifies the identities of some previously described Neotropical species and finds some species new to science. The description here of these new species expands our floristic knowledge of western South America along with our systematic knowledge of Rubiaceae, improving the basis for conservation planning and molecular analyses of these genera. Both of these genera have a center of species diversity in western South America, and both lack much basic morphological and ecological information and need further study with field observations.

\section{Methods}

This work is based on standard taxonomic methods. Additional information, including detailed specimen data and high-resolution scans of representative specimens, is available online in the Tropicos ${ }^{\circledR}$ database and its Rubiaceae Project. The genera and species treated here are arranged in alphabetical order. Types were studied variously as physical specimens, photographs, and/or high-resolution scans in JSTOR Global Plants (<https://plants.jstor.org >); locations of known duplicates of both types and paratypes are included even when they have not been seen. Specimen accession numbers in brackets are barcode numbers. Morphological terminology follows Lawrence (1951), Lorence et al. (2012), and Calderón Cruz and Taylor (2018), and order in the descriptions follows these last two works. Measurements are based on dried specimens. Comparative comments about sizes of morphological structures refer only to species of the same genus. Habitat and distribution are summarized for all the taxa treated here, but phenology is summarized for only the newly described species because only those have been comprehensively detailed. Elevational distributions are given in meters (i.e., above sea level; also sometimes called m.s.m.).

Measurements are presented here in millimeters or centimeters based on the size of the structure. Thus, the units used here may differ among species, and from those given in treatments that use standardized measurements for individual structures (e.g., Lorence et al., 2012; Taylor et al., 2004).

\section{TAXONOMY}

I. Hippotis Ruiz \& Pav., Fl. Peruv. Prodr. 33: 1794. TYPE: Hippotis triflora Ruiz \& Pav. 
Hippotis includes about 15 species of shrubs and small trees found in wet forest vegetation in Central and South America (Steyermark, 1965; Taylor, 2002; Andersson \& Rova, 2004; Calderón Cruz \& Taylor, 2018). The plants are characterized by leaves with a distinctive "lineolate" venation; caducous interpetiolar stipules that are twisted in bud; axillary inflorescences with one or a few pentamerous flowers that are relatively large and homostylous; well-developed calyx limbs with an unusual spathaceous form; tubular to funnelform, firm-textured (but not markedly fleshy) corollas that are variously white, pink, or red; and fleshy baccate fruits with numerous angled seeds. Hippotis is found at low to premontane elevations from Nicaragua to Venezuela and Peru, and its center of species diversity is in northwestern South America. The most commonly collected and widespread species is $H$. brevipes Spruce ex K. Schum. of the western Amazon basin (Calderón Cruz \& Taylor, 2018).

Hippotis has several distinctive morphological features, which were reviewed in excellent detail by Rova and Andersson (1995). The branching of at least some species is markedly sylleptic; this growth form is found in some other Rubiaceae and is usually a genus-level character. The leaf venation of Hippotis is unusual in being regularly patterned and clearly evident, with the highest-order veins and their subepidermal fiber bundles all parallel within the areoles formed by the welldeveloped tertiary and quaternary venation (Rova \& Andersson, 1995). The stipules are also distinctive in their arrangement, with two well-developed stipules that are twisted twice: first they are twisted with each other in a convolute arrangement; then the entire structure formed by the two stipules twists $180^{\circ}-360^{\circ}$ along its length. The exposed abaxial portion of each stipule is densely pubescent, while the part of it covered by the other stipule is glabrous. The stipules are acute, but often the group composed of the two stipules has an obtuse to rounded tip, because the acute tip of each individual stipule is folded down and covered by the other stipule. The spathaceous calyx limbs split along one or two sides when the corolla elongates and sometimes also develop several additional irregular shorter splits; this splitting pattern may be consistent within some Hippotis species but appears to vary within others. The calyx and corolla are both unusual in Rubiaceae in being densely fibrous. The corolla lobes are valvatereduplicate in bud and often obtuse to rounded or emarginate. The ripe fruits are ellipsoid and dark red to dark purple.

Species of Hippotis appear to have consistent corolla color and associated pollination syndromes, either white to cream or red to pink, but field study is needed to confirm and supplement herbarium specimens. Flower color characters are sometimes inaccurate on specimen labels because the red calyx limb is confused with the corolla, and the white corollas sometimes turn dark red or orange after anthesis. Corollas that are pink or red at anthesis often have relatively narrower tubes than white corollas, and apparently are pollinated by hummingbirds (Calderón Cruz \& Taylor, 2018). White corollas range from narrowly to broadly funnelform, and generally agree with the form of many hawkmoth-pollinated flowers and may be nocturnal. The white corollas are sometimes described on labels (by reliable collectors) as pale green or flushed with green externally and white internally. No reliable information has been found about flower odor or time of anthesis for any Hippotis species.

Another characteristic feature of Hippotis is its welldeveloped pubescence. Most species have dense strigose, silky, pilose, and/or hirsute pubescence on the corollas and stipules, and often they are similarly pubescent on all of their structures. The pubescence is frequently complex, at least for Rubiaceae, with many species having more than one type of trichome and these mixed together or arranged in distinct layers. The form and distribution of the pubescence seem to be consistent and distinctive for many Hippotis species (Andersson \& Rova, 2004; Calderón Cruz \& Taylor, 2018), but unfortunately even the highest-resolution digital images of herbarium specimens are usually inadequate to study the trichomes.

The inflorescences of Hippotis are variable in arrangement, from solitary flowers (i.e., one flower per leaf axil) to a cymose arrangement with two to several flowers. Inflorescence form has not been studied in detail in this genus, and some related genera have a similar range of forms so the ancestral form cannot easily be inferred. Some Hippotis species are apparently consistent in flower number and arrangement, but most vary in this regard. The developmental details of this variation are not clear at this time, so it is not yet known if the structure supporting a solitary flower represents a peduncle with the inflorescence's axes and pedicels reduced, an inflorescence axis with the peduncle and pedicels reduced, or a pedicel with the other structures reduced, nor if all the structures supporting solitary flowers have the same developmental origin. The supporting structure of a solitary flower in Hippotis is here referred to as a peduncle, following the standard terminology in cases where its developmental origin is not clearly due to reduction of the peduncle portion (Lawrence, 1951). One of the new species described here has a variable inflorescence arrangement: "peduncle" in the description of $H$. vasquezii C. M. Taylor refers to either the structure that supports a solitary flower, or the structure that supports a group of flowers and extends from the stem to a branching point. In this species, the term "pedicel" is used only when the inflorescence has more than one flower borne from a common peduncle, 
and here it refers to the structure that extends from the flower downward to another supporting structure, either a peduncle or an axis; thus, pedicels are not always present in the inflorescences of $H$. vasquezii. When more than one flower is produced in a single leaf axil and each is borne on a separate, unbranched supporting structure that arises from the stem, this arrangement is called "fasciculate" and each of the supporting structures is referred to here as a peduncle.

Hippotis shares its distinctive leaf venation, twisted interpetiolar stipules, axillary inflorescences, flower form, and fruit form with Pentagonia Benth., Tammsia H. Karst., and Sommera Schltdl., and these were classified together in the tribe Hippotideae by Rova and Andersson (1995). A later molecular systematic study by Kainulainen et al. (2010) found these four genera grouped together within an expanded tribe Condamineae. Pentagonia can be recognized by its thickly fleshy corollas and leaves with the higher-order venation not visible, although the subepidermal fiber bundles of the quaternary veins are sometimes evident on dried specimens. Sommera differs from Hippotis by its flowers borne in cymes of a dozen or more and rather fleshy corollas. Tammsia comprises a single species from Venezuela that can be separated from Hippotis by its regularly 3 -lobed calyx limb.

Neotropical Hippotis has never been studied as a whole and has not been surveyed broadly since Steyermark's overview (1965) for northern and Amazonian South America. The identities of several Hippotis species have been unclear in general and further blurred by collections from the botanical exploration in the last two decades, but recent study now clarifies these. The most problematic species has been $H$. brevipes, which appears to be a notably variable species with several wellmarked forms that are distinctive but sympatric and morphologically not distinct (Calderón Cruz \& Taylor, 2018). Hippotis mollis Standl. has also been difficult or controversial to diagnose morphologically, but its circumscription is reevaluated and narrowed here as discussed under H. ecuatoriana C. M. Taylor.

Hippotis comosa L. Andersson \& Rova and H. stellata C. M. Taylor \& Rova are similar morphologically and sympatric in Ecuador (Andersson \& Rova, 2004), and their separation has also been controversial at times. More specimens now document these species well and show characters that consistently distinguish them. Hippotis stellata is characterized by the combination of its relatively large white corollas and unique trichome arrangement on the abaxial leaf surface. This species overall has shorter than average trichomes for Hippotis species, and its leaves abaxially have a distinctive arrangement of numerous short trichomes in separated groups along the tertiary veins. These trichomes are so closely set that the groups appear in casual observation to be single stellate trichomes. These groups characteristically have up to a dozen hispidulous trichomes ca. $0.4 \mathrm{~mm}$ long and one trichome that is two to three times as long as these short ones (Andersson \& Rova, 2004: fig. 3C). Characteristically for Hippotis, these distinctive trichome groups are mixed with scattered longer trichomes $0.5-1.8 \mathrm{~mm}$. The corollas of $H$. stellata are sometimes described on labels as red, but those corollas appear to be old or those notes seem to be confused (this last is a common problem in Hippotis, as discussed above). The distinctive characters of $H$. stellata are also found on the type of $H$. grandiflora Steyerm., which was not studied in the previous works on Central American and Ecuadorian Hippotis. Steyermark's type is not separable from H. stellata and is an older name for this species, so $H$. stellata is here synonymized under $H$. grandiflora; this species is found from eastern Panama through northwestern Ecuador. Hippotis comosa also has relatively large corollas, but in contrast to $H$. grandiflora these are pink or red and the leaves of $H$. comosa abaxially have pubescence that is "strigose, [this] indumentum uniform with hairs mainly 1.5-2.5 mm long" (Andersson \& Rova, 2004: 14). Hippotis comosa is endemic to northwestern Ecuador.

Another problematic species studied here is Hippotis albiflora $\mathrm{H}$. Karst. This species has been circumscribed more broadly by recent authors (Taylor, 1997; Andersson \& Rova, 2004) than by Steyermark (1965) in Venezuela and Colombia. These recent authors included in H. albiflora plants from Ecuador and Peru that share relatively short trichomes, white corollas, and similar leaf shape with the Venezuelan plants, but differ from the Venezuelan and Colombian plants in pubescence form, leaf and flower size, and elevational range. Here $H$. albiflora is again circumscribed following Steyermark (1965, 1974), but with its geographic range extended by new collections. Steyermark reported this species from western Venezuela through scattered localities in western Colombia, and it is now also documented from the isolated Sierra de La Macarena (Idrobo \& Jaramilllo 2070, MO), from northern Colombia (e.g., Delprete \& Cortés-Ballén, 2016), and widely in western Colombia (e.g., Espina 2021, Forero et al. 7588, García Cossio 149, all MO). The plants from the Chocó region of western Colombia have, on average, smaller and narrower leaves along with longer pedicels and peduncles, but they are not fully separable morphologically from Venezuelan plants (including the type). The plants newly excluded here from $H$. albiflora are described below as the new species $H$. elegantula C. M. Taylor \& M. Calderón and H. vasqueziana C. M. Taylor.

1. Hippotis antioquiana C. M. Taylor, sp. nov. TYPE: Colombia. Antioquia: mpio. Santo Domingo, correg. El Limón, sítio La Chorrera, cuenca del río 
Nusito, $6^{\circ} 30^{\prime} \mathrm{S}, 75^{\circ} 04^{\prime} \mathrm{W}, 1300 \mathrm{~m}, 12$ Jan. 1994 , R. Callejas, A. J. Bornstein, A. Duque \& F. Giraldo 11101 (holotype, HUA-090382!; isotype, MO04643960!). Figure 1A.

Diagnosis. Hippotis antioquiana C. M. Taylor differs from H. comosa L. Andersson \& Rova by its smaller flowers, with the calyx limb $18-20 \mathrm{~mm}$ and the corolla tube ca. $27 \mathrm{~mm}$.

Shrubs and small trees, flowering at $3 \mathrm{~m}$, to $8 \mathrm{~m}$; stems flattened becoming terete, densely hirsute with trichomes 1.5-2 mm. Leaves opposite; blade elliptic to oblanceolate or obovate, $8.5-22 \times 3-8 \mathrm{~cm}$, at base acute to obtuse, at apex acute to usually acuminate with tips 5-15 mm, drying papyraceous, adaxially sparsely to moderately hispidulous to hirsute with trichomes $0.3-2 \mathrm{~mm}$, abaxially densely hirsute with trichomes $1-2 \mathrm{~mm}$; secondary veins 8 to 10 pairs, reticulating or occasionally looping directly to interconnect near margins; petiole $0.5-2.2 \mathrm{~cm}$, densely hirsute with trichomes 1-2 mm; stipules triangular, caducous, $5-10 \mathrm{~mm}$, acute, abaxially densely hirsute with trichomes $1.5-2$ $\mathrm{mm}$. Inflorescences with flowers solitary or 2 and fasciculate in each axil; peduncles $3-10 \mathrm{~mm}$, densely hirsute with trichomes $1.5-3 \mathrm{~mm}$; bracts reduced or caducous and not seen. Flowers with hypanthium ellipsoid, 3-4 mm, densely hirsute with trichomes $2-3 \mathrm{~mm}$; calyx limb 18-20 mm, opening by 2 or 3 slits into acute segments, abaxially densely hirsute with trichomes $1-3 \mathrm{~mm}$, adaxially sparsely strigillose with trichomes $0.3-0.5 \mathrm{~mm}$; corolla funnelform, red, externally densely strigose with trichomes $1-3 \mathrm{~mm}$, internally not seen, tube ca. $27 \mathrm{~mm}$, ca. $4 \mathrm{~mm}$ diam. near middle, lobes elliptic, ca. $5 \mathrm{~mm}$, obtuse to rounded; anthers not seen; style ca. $9 \mathrm{~mm}$, glabrous, stigmas ca. $1.5 \mathrm{~mm}$. Fruits not seen.

Habitat, distribution, and phenology. This species is found in wet forest at $1300-1800(-2800) \mathrm{m}$ in northern Colombia, on the northern and eastern slopes of the Cordillera Central and the western slopes of the Cordillera Oriental; it has been collected in flower in January through August and October, and in fruit in April.

Notes. Hippotis antioquiana is characterized by its abundant, softly hirsute pubescence, medium-sized leaves, flowers borne singly or in pairs on short peduncles, densely hirsute and relatively short calyx limbs, and red, rather short corollas. Very few corollas have been seen; these are on the type collection and were not dissected. This new species is found in Antioquia Department in northwestern Colombia, and the epithet refers to this place. The area where this was collected appears to be floristically distinctive, with some other uncommon Rubiaceae species also known only from there, or sometimes also found on the other side of the
Magdalena River valley on the northwestern slopes of the Cordillera Oriental in Santander (e.g., Palicourea denslowiae J. H. Kirkbr.).

Hippotis antioquiana is similar in pubescence, general aspect, leaf form, flower form, and corolla color to H. comosa of northwestern Ecuador. Hippotis comosa can be separated by its longer calyx limbs, $33-35 \mathrm{~mm}$, and longer corollas, with tubes $35-50 \mathrm{~mm}$ long.

Paratypes. COLOMBIA. Antioquia: mpio. Amalfi, vereda El Oso, 13-16 km de Amalfi a Medellín, Cordillera Central, J. Betancur et al. 904 (HUA n.v., MO), vereda Las Animas, D. Tuberquia \& A. Zapata 1240 (JAUM), vereda Guabito, bosque Caracoli, C. Zapata \& M. Castaño 26 (HUA), vereda Salazar, finca Bodega Vieja, cuenca del río Riachon, J. Betancur et al. 13127 (HUA, JAUM); mpio. Anorí, vereda Santa Gertrudis, Finca La Estrella, T. Arias et al. 198 (HUA), vereda Los Sauces cerca de las quebradas El Oso y Los Sauces, H. David et al. 1735 (HUA); mpio. Briceño, vereda El Anime, sector La Escuela El Anime, margen derecha aguas abajo río Espiritu Santo, P. Trujillo et al. 4358 (HUA); mpio. Donmatías, vereda La Pradera, monte el Zancudo, E. Correa \& A. L. Montoya 1184 (JAUM); mpio. San Rafael, vereda La Clara, Reserva Natural Manantiales del Campo, D. González et al. 41 (HUA); mpio. San Luis, vereda Manizales, $12 \mathrm{~km}$ de San Luis en la via San Luis-San Carlos, R. Callejas et al. 4261 (COL image, HUA, MO); mpio. Santo Domingo, Vereda El Limón, E. Quintero et al. 10 (HUA, JAUM), correg. Santiago, vertiente oriental de la Cordillera Central, A. Camargo-García et al. 833 (HUA); mpio. Yolombó, Vereda Sabanitas, Finca Oasis, R. Callejas et al. 8012 (HUA). Norte de Santander: mpio. Bochalema, vereda El Talco, La Molienda, J. G. Vélez \& N. G. Correa 4005 (JAUM); mpio. Cucutá, vereda Brazil, H. Mendoza et al. 3881 (JAUM); mpio. Cucutilla, vereda El Carrizal, sector Sisavita, arriva de la casa de Francisco Pulido, H. Mendoza et al. 14748 (HUA). Santander: mpio. Suaita, correg. San José de Suaita, vereda Marbella, J. Betancur et al. 10665 (HUA), mpio. Socorro, Vereda Alto de Reinas, Finca San Luis, J. G. Vélez et al. 6122 (HUA).

2. Hippotis ecuatoriana C. M. Taylor, sp. nov. TYPE: Ecuador. Pastaza: pozo petrolero "Garza" de TENNECO, ca. $35 \mathrm{~km}$ NE de Montalvo, $1^{\circ} 49^{\prime} \mathrm{S}$, $76^{\circ} 42^{\prime} \mathrm{W}, 260 \mathrm{~m}, 2-12$ July 1989, V. Zak \& $S$. Espinoza 4659 (holotype, QCNE-20404 image!; isotypes, MO-3792184!, G n.v., GB n.v., K n.v., NY n.v.). Figure 2B, C.

Diagnosis. Hippotis ecuatoriana C. M. Taylor is distinguished from $H$. mollis Standl. by its smaller flowers, with the corolla ca. $24 \mathrm{~mm}$, and appressed pubescence on the calyx and hypanthium.

Shrubs and trees, flowering at $2 \mathrm{~m}$, to $20 \mathrm{~m}$; stems flattened becoming terete, when young densely strigose with trichomes $0.8-1.2 \mathrm{~mm}$ and sometimes also sparsely strigillose with trichomes $0.2-0.4 \mathrm{~mm}$, with both types of trichome deciduous. Leaves opposite; blade elliptic to obovate, $10.5-20.5 \times 5.5-11 \mathrm{~cm}$, at base cuneate to obtuse, at apex shortly acuminate with tips $3-10 \mathrm{~mm}$, drying papyraceous, adaxially glabrous to sparsely hispidulous with trichomes $0.3-0.5 \mathrm{~mm}$, abaxially sparsely 


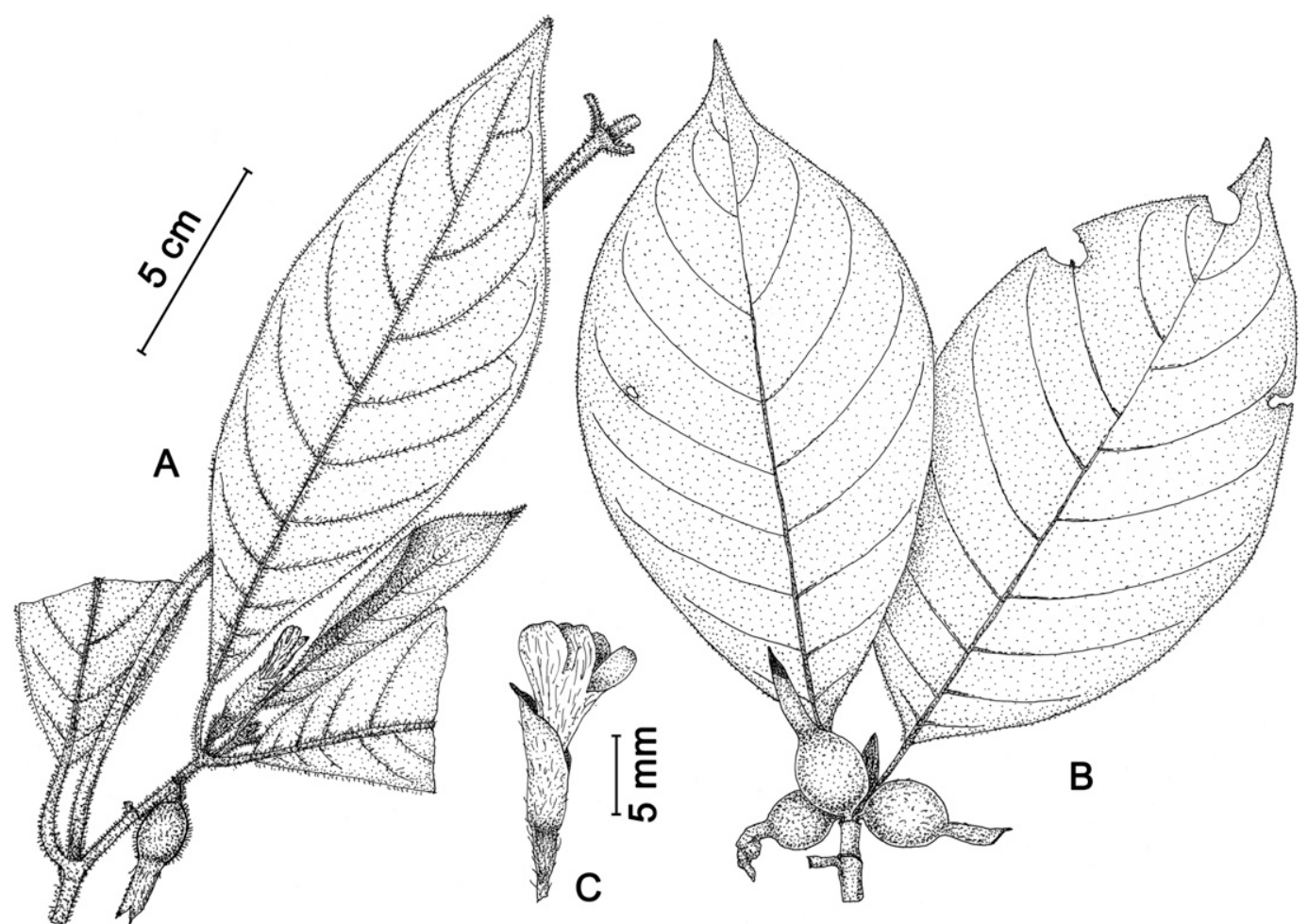

Figure 1. -A. Hippotis antioquiana C. M. Taylor, flowering branch. B, C. Hippotis vasqueziana C. M. Taylor. -B. Fruiting branch. - C. Flower at anthesis. A based on R. Callejas, A. J. Bornstein, A. Duque \& F. Giraldo 11101. B based on R. Vásquez et al. 14154. C based on J. J. Pipoly, R. Vásquez, N. Jaramillo \& R. Ortíz 12439. A, B to 5-cm scale.

to moderately pubescent on costa and other venation with stiff strigose trichomes $0.8-2 \mathrm{~mm}$ and moderately to densely hirtellous to strigillose on lamina with soft trichomes $0.2-1 \mathrm{~mm}$; secondary veins 7 to 9 pairs, reticulating or usually looping directly to interconnect near margins; petiole 1-2.2 cm, densely strigose with trichomes $0.8-1.2 \mathrm{~mm}$ and sometimes also sparsely strigillose with trichomes $0.2-0.4 \mathrm{~mm}$; stipules triangular, caducous, 7-9 mm, acute, abaxially densely strigose with trichomes $0.8-1.2 \mathrm{~mm}$ and sometimes also sparsely strigillose with trichomes $0.2-0.4 \mathrm{~mm}$. Inflorescences with flowers solitary or 2 to 3 and fasciculate or cymose in each axil; peduncle 1-7 mm, densely strigose with trichomes $1-3 \mathrm{~mm}$ and sometimes also strigillose with trichomes $0.2-0.4 \mathrm{~mm}$; bracts reduced or caducous and not seen; pedicels when present 2-6 mm, pubescent similarly to peduncle. Flowers with hypanthium obconic to slenderly ellipsoid, 4-5 mm, densely strigose with trichomes $1-3 \mathrm{~mm}$ and sometimes also strigillose with trichomes $0.2-0.4 \mathrm{~mm}$; calyx limb 18-20 mm, opening by 2 or 3 slits into acute segments, abaxially densely strigose with trichomes $1-3 \mathrm{~mm}$ and sometimes also strigillose with trichomes $0.2-0.4 \mathrm{~mm}$, adaxially moderately to sparsely strigose with trichomes 0.8-2.5 mm; corolla tubular-funnelform, white, externally densely strigose to sericeous with trichomes $2-3 \mathrm{~mm}$, internally not seen, tube ca. $24 \mathrm{~mm}$, ca. $3 \mathrm{~mm}$ diam. near middle, lobes elliptic, ca. $3 \mathrm{~mm}$, rounded; anthers and stigmas not seen. Fruits ellipsoid, 15-20 $\times$ 10-12 mm, moderately to densely strigose with trichomes 1-3 mm and sometimes also strigillose with trichomes $0.2-0.4 \mathrm{~mm}$, mature color unknown; seeds irregularly angled, $1.5-2 \mathrm{~mm}$.

Habitat, distribution, and phenology. This species is found in wet forest on clay soils at $260-360 \mathrm{~m}$ in the western Amazon basin, in central-southern Ecuador; it has been collected in flower in July and September, and with well-developed fruits in January, February, April, and May.

Notes. Hippotis ecuatoriana is characterized by its medium-sized leaves that are abaxially hirtellous, inflorescences mostly in short fascicles, well-developed calyx limbs with appressed pubescence, and mediumsized white corollas. Only one mature flower has been seen, so this was not dissected. The appressed pubescence of the calyx limb occasionally becomes spreading as the fruits mature. This species is only known from Amazonian central-southern Ecuador, and its epithet refers to this country. Some other Rubiaceae genera 


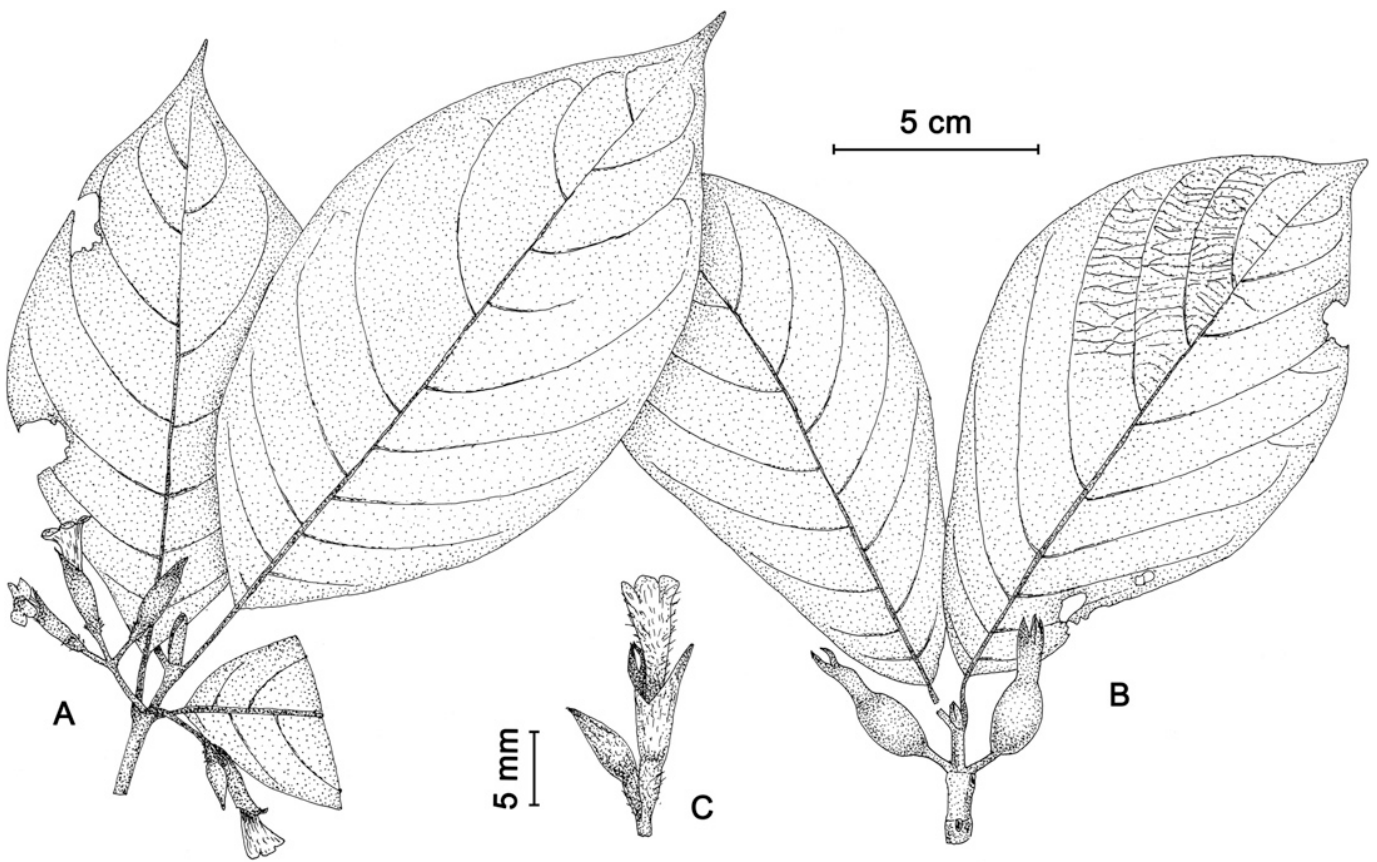

Figure 2. - A. Hippotis elegantula C. M. Taylor \& M. Calderón, flowering branch. B, C. Hippotis ecuatoriana C. M. Taylor. -B. Fruiting branch. - C. Part of inflorescence with one flower in bud and one flower at anthesis. A based on D. Neill 7541 . B based on D. Rubio 126. C based on V. Zak \& S. Espinoza 4659. A, B to 5-cm scale.

have species with apparently localized ranges in this region (e.g., several species of Joosia H. Karst.; Taylor, 2017a), though whether this is due to the floristic distinctiveness of this region or our poor knowledge of the area is not clear. The type specimen was originally labeled as collected in Morona-Santiago Province, but that geographical error was subsequently corrected in the Tropicos ${ }^{\circledR}$ database.

The plants named here as Hippotis ecuatoriana were included by Andersson and Rova (2004) in H. mollis, which was morphologically very variable in their circumscription. Most of the Amazonian plants they included in $\mathrm{H}$. mollis have red corollas and are now included in $H$. brevipes (Calderón Cruz \& Taylor, 2018). Some other plants from Amazonian Ecuador that Andersson and Rova included in $\mathrm{H}$. mollis have white flowers and a general form similar to the type of that name, from central Colombia, but differ from it in their hirtellous pubescence on the lower leaf surface and smaller flowers with appressed pubescence. With the red-flowered Amazonian plants excluded from H. mollis, these white-flowered Amazonian plants are now markedly disjunct geographically and distinct morphologically from other populations of $H$. mollis. These smaller-flowered Amazonian plants are separated here as $H$. ecuatoriana, leaving $H$. mollis a morphologically well-characterized species restricted to the Magdalena River valley in northern Colombia. In this narrowed circumscription H. mollis has leaves with densely hirsute, spreading pubescence on the lower leaf surface, hypanthium, and calyx limb, longer calyx limbs $22-26 \mathrm{~mm}$, larger corollas with tubes $30-40 \mathrm{~mm}$ long, and a habitat mainly if not entirely on sandstone substrates.

Paratypes. ECUADOR. Orellana: Parque Nacional Yasuní, $6 \mathrm{~km}$ E del helipuerto pasando 4 veces el río Shiripuno, F. Hurtado et al. 512 (MO, QCNE). Pastaza: $10 \mathrm{~km}$ al S del límite Napo [i.e., Orellana]-Pastaza, via Auca ca. del río Tigüino al S del Pozo Tigüino 2, W. Palacios 3467 (MO, QCNE); via Auca, $115 \mathrm{~km} \mathrm{~S}$ de Coca, ca. de y hasta $6 \mathrm{~km}$ al S del río Tigüino, carretera Petro-Canada en construcción, D. Rubio 111 (MO, QCNE), 126 (MO, QCNE), V. Zak 3928 (MO, QCNE), V. Zak \& D. Rubio 4269 (MO, QCNE), 4288 (MO, QCNE); cantón Pastaza, Pozo Petrolero Ramírez, 20 km al S de Curaray, V. Zak \& S. Espinoza 4891 (JAUM, MO, QCNE n.v.), 5109 (ECUAMZ, MO, QCNE).

3. Hippotis elegantula C. M. Taylor \& M. Calderón, sp. nov. TYPE: Ecuador. Napo [Sucumbíos]: de la carretera entre Reventador y Lumbaqui $10 \mathrm{~km}$ al S, río Tigre, $00^{\circ} 05^{\prime} \mathrm{S}, 77^{\circ} 24^{\prime} \mathrm{W}, 800$ m, 6 Dec. 1986 , D. Neill 7541 (holotype, QCNE-188459 image!; isotypes, MO-3501478!, NY n.v.). Figure 2A.

Diagnosis. Hippotis elegantula C. M. Taylor \& M. Calderón is distinguished from $H$. albiflora $\mathrm{H}$. Karst. by its smaller corollas and smaller fruits.

Shrubs, flowering at $1.5 \mathrm{~m}$, to $6 \mathrm{~m}$; stems flattened becoming terete, glabrous or occasionally moderately to 
densely strigose with trichomes ca. $1 \mathrm{~mm}$ and sparsely strigillose with trichomes ca. $0.2 \mathrm{~mm}$. Leaves opposite; blade elliptic to oblanceolate or obovate, $6-21 \times$ $2-10 \mathrm{~cm}$, at base acute to obtuse, at apex acute to usually acuminate with tips $5-10 \mathrm{~mm}$, drying papyraceous, adaxially sparsely hispidulous with trichomes 0.3-0.5 mm then sometimes becoming glabrescent, abaxially and near margins sparsely to densely strigose on costa and secondary veins with trichomes 0.8-1.2 mm and sparsely to densely strigillose on costa, secondary veins, and higher-order venation with trichomes $0.2-0.5 \mathrm{~mm}$; secondary veins 5 to 8 pairs, reticulating or sometimes looping to interconnect near margins; petiole $0.5-3 \mathrm{~cm}$, moderately to densely strigose with trichomes $0.8-1.2 \mathrm{~mm}$ and sometimes deciduous, also sparsely to densely strigillose with trichomes $0.2-0.5 \mathrm{~mm}$; stipules interpetiolar, caducous, triangular, 5-18 mm, acute, abaxially densely strigillose to strigose with trichomes $0.3-1.2 \mathrm{~mm}$. Inflorescences with flowers solitary or 3 and fasciculate in each axil; peduncle $0.2-1.2 \mathrm{~cm}$, densely strigose with trichomes $0.8-1.2 \mathrm{~mm}$ and sparsely to densely strigillose with trichomes $0.2-0.5 \mathrm{~mm}$; bracts reduced or narrowly triangular to linear, 3-4 $\mathrm{mm}$, deciduous; pedicels $3-8 \mathrm{~mm}$, with pubescence similar to that of peduncle. Flowers with hypanthium obconic, 3-4 mm, densely strigose with trichomes $0.8-1.2 \mathrm{~mm}$ and sparsely strigillose with trichomes $0.2-0.5 \mathrm{~mm}$; calyx limb $10-20 \mathrm{~mm}$, opening by 1 or sometimes 2 slits into acute segments, abaxially sparsely to densely strigose with trichomes $0.8-1.2 \mathrm{~mm}$ and sometimes also sparsely strigillose with trichomes $0.2-0.5 \mathrm{~mm}$, adaxially glabrous; corolla tubular or tubular-funnelform, white, externally moderately to densely strigose with trichomes 1-1.2 mm and sparsely silky-strigillose with trichomes $0.2-0.5 \mathrm{~mm}$, internally not seen, tube $16-22 \mathrm{~mm}$, 2.2-3 mm diam. near middle, lobes elliptic, ca. $4 \mathrm{~mm}$, obtuse to rounded; anthers and stigmas not seen. Fruits ellipsoid to subglobose, 8-10 $\times 8 \mathrm{~mm}$, densely strigose with trichomes $0.8-1.2 \mathrm{~mm}$ and sparsely strigillose with trichomes $0.2-0.5 \mathrm{~mm}$, mature color unknown, with calyx limb sometimes tardily splitting into 3 or 4 segments; seeds angled, to $1.5-2 \mathrm{~mm}$.

Habitat, distribution, and phenology. This species is found in wet forest at $350-1300 \mathrm{~m}$ in the western Amazon basin of Ecuador; it has been collected in flower in October and December, and with welldeveloped fruits in February, April, May, August, November, and December.

Notes. Hippotis elegantula is characterized by its medium-sized leaves with strigillose pubescence, inflorescences with slender, well-developed peduncles and pedicels, medium-sized calyx limbs, rather small white corollas, and somewhat small fruits. This new species appears to have the smallest flowers in the genus, which are delicate and showy, and its epithet refers to this form. Few mature flowers are documented by collections, so the corollas seen have not been dissected. Hippotis elegantula is found in the Amazon basin from north-central to southern Ecuador, apparently in a rather restricted elevational or vegetation zone. Some other Rubiaceae genera also have species that share this habitat and relatively restricted range (e.g., species of Joosia; Taylor, 2017a).

Hippotis elegantula was included in the circumscription of $H$. albiflora by Andersson and Rova (2004), but more collections of both species now show these are distinct as noted above in the discussion of Hippotis. Hippotis albiflora can be recognized by its leaves with hirtellous (i.e., short and spreading) pubescence, corolla tubes 26-33 mm long, well-developed fruits 15-20 $\times$ 5-10 mm, and distribution from western Venezuela to northern and southwestern Colombia. These two species appear to be fully separated geographically, though much of the area between their ranges is not well explored botanically.

Paratypes. ECUADOR. Morona-Santiago: parroq. El Copal, San José Grande, cuenca del río Paute entre el río Cardenillo Grande y Cardenillo Chico, C. Cerón \& G. Benavides 14106 (MO, QCNE). Napo: private lodge Hakuna Matata, ca. $5 \mathrm{~km}$ NE of Archidona, J. Homeier 2414 (GOET n.v., MO); Parque Nacional Sumaco-Galeras, Cordillera Galeras, J. Homeier \& M. A. Chinchero 1993 (GOET n.v., MO, QCNE), S. Moritz et al. 64 (GOET n.v., MO); carretera Hollín-Loreto, Km. 25, centro Challuayacu, F. Hurtado \& A. Alvarado 1061 (MO, QCNE); carretera en construcción Cotundo-Coca, 15 km al E de la carretera Baeza-Tena, faldas del Volcán Sumaco, D. Neill \& W. Palacios 7618 (MO, QCNE n.v.). Sucumbíos [as Napo]: cantón Gonzalo Pizarro, río Tigre, afluente del río Dashiño, entrando en el Km. 73 de la carretera Lumbaqui-El Reventador, W. Palacios \& D. Neill 1603 (MO, QCNE). Orellana: zona de amortiguamiento del Parque Nacional Sumaco, líneas sísmicas de Amoco, río Pujuno, sector Jan Pio Montúfar, M. Tirado \& B. Grefa 2091 (ECUAMZ, MO, QCNE n.v.). Pastaza: along rd. to Río Anzu, $17.1 \mathrm{~km} \mathrm{~N}$ of Mera, $3.5 \mathrm{~km} \mathrm{~N}$ of Río Anzu, T. B. Croat et al. 88675 (MO, QCNE); cantón Pastaza, parroq. Curaray, Pozo Villano 2 de Arco, $2 \mathrm{~km}$ del pueblo de Villano, G. Tipaz et al. 555 (MO, QCNE), entre los ríos Iquino y Villano, M. Tirado et al. 4 (ECUAMZ, MO, QCNE), Villano-La Independencia, $H$. Vargas et al. 1619 (QCNE). Zamora-Chinchipe: along rd. from Zamora to Romerillos, $6.6 \mathrm{~km} \mathrm{~S}$ of bridge over Río Bombuscaro, vic. of La Pituca, T. B. Croat \& M. Menke 89718 (MO, QCNE); Namirez, ca. $10 \mathrm{~km}$ NE of Zamora on hwy. toward Zumbi, J. R. Grant et al. 02-4257 (MO); Shaime, sendero hacia el Hito, J. Jaramillo 14440 (MO, QCA n.v.).

4. Hippotis vasqueziana $C$. M. Taylor, sp. nov. TYPE: Peru. Loreto: prov. Maynas, Indiana, Reserva Explorama (Yanamono), $25 \mathrm{~km} \mathrm{NE} \mathrm{Iquitos} \mathrm{a} \mathrm{lo}$ largo del río Amazonas, $3^{\circ} 30^{\prime} \mathrm{S}, 72^{\circ} 50^{\prime} \mathrm{W}, 90 \mathrm{~m}$, 26 Sep. 1990, J. J. Pipoly, R. Vásquez, N. Jaramillo \& R. Ortíz 12439 (holotype, MO-5468788!; isotypes, AMAZ n.v., MO-4258964!). Figure 1B, C. 
Diagnosis. Hippotis vasqueziana C. M. Taylor is distinguished from $H$. albiflora $\mathrm{H}$. Karst. by its more robust habit, often larger leaves, shorter and more broadly funnelform corollas, and larger fruits.

Trees, flowering at $4 \mathrm{~m}$, to $15 \mathrm{~m}$; stems flattened becoming terete, densely strigose with trichomes $0.8-1 \mathrm{~mm}$ and also moderately to densely pilosulous or hirtellous with trichomes $0.2-0.5 \mathrm{~mm}$. Leaves opposite; blade elliptic to obovate, $12-36 \times 7-19 \mathrm{~cm}$, at base cuneate to broadly obtuse, at apex acuminate with slender tip 10-25 mm, drying chartaceous, adaxially glabrous, abaxially densely hirtellous on veins and sparsely hirtellous on lamina with trichomes $0.2-0.5 \mathrm{~mm}$, and densely strigose on costa and secondary veins with trichomes $0.8-1 \mathrm{~mm}$; secondary veins 9 to 11 pairs, reticulating or sometimes looping directly to interconnect near margins; petiole $0.8-2.7 \mathrm{~cm}$, densely strigose with trichomes $0.8-1 \mathrm{~mm}$ and also moderately to densely pilosulous or hirtellous with trichomes $0.2-0.5 \mathrm{~mm}$; stipules caducous, triangular, $15-20 \mathrm{~mm}$, acute, adaxially densely strigose with trichomes $0.8-1 \mathrm{~mm}$ and also moderately to densely pilosulous or hirtellous with trichomes $0.2-0.5 \mathrm{~mm}$. Inflorescences with flowers solitary or usually 3 to 5 in 1 subsessile cyme in each axil; peduncle to $0.2 \mathrm{~cm}$, densely strigose with trichomes $0.8-1.2 \mathrm{~mm}$ and sparsely to moderately hirtellous with trichomes $0.1-0.5 \mathrm{~mm}$; bracts reduced or caducous and not seen; pedicels 4-9 mm, with pubescence similar to that of peduncle. Flowers with hypanthium slenderly cylindrical, $4-5 \mathrm{~mm}$, densely strigose with trichomes $0.8-1 \mathrm{~mm}$ and sparsely hirtellous with trichomes $0.1-0.2 \mathrm{~mm}$; calyx limb 18-21 mm, opening by 1 or 2 slits into acute segments, abaxially sparsely to densely strigillose or silky-strigose with trichomes $0.5-1 \mathrm{~mm}$, adaxially glabrous; corolla rather broadly funnelform, white, externally densely strigose to sericeous with trichomes $1-2 \mathrm{~mm}$, internally glabrous, tube 19-26 mm, 4-5 mm diam. near middle, lobes 5, elliptic, 4-8 mm, obtuse to rounded or emarginate; anthers included, ca. $5 \mathrm{~mm}$, positioned ca. $5 \mathrm{~mm}$ below top of corolla tube on filaments ca. $7 \mathrm{~mm}$, densely strigose in basal $1-2 \mathrm{~mm}$ with trichomes ca. $1 \mathrm{~mm}$; style ca. $12 \mathrm{~mm}$, stigmas ca. $2 \mathrm{~mm}$. Fruits ellipsoid to subglobose, $20-25 \times 17-18 \mathrm{~mm}$, brown, fibrous to woody, moderately strigose with trichomes $0.8-1 \mathrm{~mm}$; seeds irregularly angled, $2.5-3 \mathrm{~mm}$.

Habitat, distribution, and phenology. This species is found in wet, non-inundated forest ("terra firme") at 90-100 m near the Amazon River in northeastern Peru; it has been collected in flower in August, September, and November, and with well-developed fruits in January, February, May, June, July, and September.

Notes. Hippotis vasqueziana is characterized by its robust hirtellous leaves, shortly pedicellate flowers borne singly or in few-flowered groups, well-developed calyx limbs, funnelform white corollas, and ellipsoid fruits of relatively large size. Its leaves are perhaps the largest in Hippotis. Hippotis vasqueziana has been collected frequently at various sites near Iquitos, Peru, especially in the intensive botanical inventories directed by Rodolfo Vásquez (Vásquez Martínez, 1997). That study represents only a small part of his contributions to the exploration and study of the Peruvian flora, and the name of this species honors him. Some of the specimens cited below from the Explorama Tourist Camp are sterile, but clearly belong to $H$. vasqueziana and show that this species is locally common in at least some sites.

Hippotis vasqueziana was misidentified by Taylor (1997) as H. albiflora, and these are similar and probably closely related but are distinct ecologically and in geographic range. Hippotis albiflora can be separated by its generally smaller habit, as a slender shrub and small tree usually $4 \mathrm{~m}$ tall or shorter, along with its often smaller leaf blades $15-28 \times 5.5-11.5 \mathrm{~cm}$, narrowly funnelform corollas with tubes $26-33 \mathrm{~mm}$ long, welldeveloped fruits 15-20 mm long, and distribution at 490-1600 m from western Venezuela to western Colombia. The corolla tubes of H. albiflora and H. vasqueziana have similar diameters, $4-5 \mathrm{~mm}$ near the middle and $7-10 \mathrm{~mm}$ at the top, but because of the difference in their lengths, their overall forms differ and the corolla tubes of $H$. albiflora are relatively narrower. The longest corollas of $H$. vasqueziana do reach the length of the smallest corollas of $\mathrm{H}$. albiflora, but the longest corolla tubes of $H$. vasqueziana are also the widest, while the shortest tubes of $\mathrm{H}$. albiflora are the narrowest, so that corollas of similar size differ among species in shape.

Paratypes. PERU. Loreto: prov. Maynas, distr. Indiana, trocha a Mazán, NE Iquitos, $R$. Vásquez et al. 1329 (AMAZ n.v., MO), Explorama Tourist Camp, Quebrada Yanamono, C. Díaz et al. 1133 (MO), A. Gentry et al. 27890 (AMAZ n.v., MO), 27909 (AMAZ n.v., MO), 39678 (AMAZ n.v., MO), 42206 (AMAZ n.v., MO), 54272 (AMAZ n.v., MO), 54561 (AMAZ n.v., MO), 54640 (AMAZ n.v., MO), 55770 (AMAZ n.v., MO), 61671 (AMAZ n.v., MO), 65712 (AMAZ n.v., MO), C. Grández et al. 3686 (AMAZ n.v., MO), 3948 (AMAZ n.v., MO), 4104 (AMAZ n.v., MO), 4108 (AMAZ n.v., MO), I. Huamantupa et al. 4743 (MO), I. Huamantupa \& N. Jaramillo 4774 (MO), $R$. Vásquez \& N. Jaramillo 4099 (AMAZ n.v., MO), 11061 (AMAZ n.v., MO), 11065 (AMAZ n.v., MO), R. Vásquez et al. 12102 (AMAZ n.v., MO); distr. Iquitos, Río Nanay, Bellavista, carretera caserio de Lupuna to Santa Clotilde, M. Rimachi Y. 1787 (MO); Santa María de Ojeal, ca. $10 \mathrm{~km}$ below mouth of Río Nanay, S. McDaniel \& M. Rimachi Y. 17868 (MO), 20731 (MO); distr. Mazán, varadera de Mazán, T. B. Croat 20769 (MEDEL, MO), $3 \mathrm{~km}$ below Baradero de Mazán, S. McDaniel \& M. Rimachi Y. 23112 (MO), Río Amazonas, carretera de Mazán, M. Rimachi Y. 3046 (MO).

II. Schradera Vahl, Eclog. Amer. 1: 35.1796 [1797]. TYPE: Schradera capitata Vahl, nom. illeg. $\equiv$ Fuchsia involucrata $\mathrm{Sw} . \equiv$ Schradera involucrata (Sw.) K. Schum. 
Schradera includes at least 45 species of rather succulent plants found widely in wet tropical forests of the Neotropics. Most species have a climbing habit, and all Schradera species are characterized by ligulate, deciduous, usually obtuse to rounded stipules that are pressed flatly together and held erect in bud; terminal or rarely axillary, capitate inflorescences or solitary flowers that are enclosed by a distinctive tubular involucre; 5 - to 6(to 10)-merous distylous flowers without calycophylls; tubular truncate calyx limbs; well-developed, thickly fleshy white corollas with the lobes valvate in bud; and fleshy baccate fruits with numerous small, angled seeds. The majority of Schradera species have a lianescent habit that is unusual in Rubiaceae, germinating as terrestrial or perhaps epiphytic plants and climbing by adventitious roots to high levels of the forest (Steyermark, 1963; Puff et al., 1993; Lorence et al., 2012; Taylor, pers. obs.). One of the new species described below, however, is confirmed as a small tree and this habit is newly reported for this genus in the Neotropics.

Schradera was reviewed briefly but comprehensively by Steyermark (1963), who knew it as a Neotropical genus. This genus belongs to the tribe Schradereae (Puff et al., 1993), which is found in the Neotropics, southeastern Asia, and Malesia. Puff et al. reviewed this tribe morphologically and concluded that the Paleotropical genus Lucinaea DC. is not separable from Neotropical Schradera and synonymized these. They studied the Paleotropical species in some detail, but the Neotropical species have not been reviewed since Steyermark's survey and never in morphological detail. An updated genus description and regional treatments were presented by Taylor (2003), Taylor et al. (2004), and Lorence et al. (2012). In the Neotropics, Schradera has several areas of species richness and endemism: southern Central America through western Colombia, the Guayana Highlands, and Andean Ecuador and Peru. Schradera subandina K. Krause is apparently the most widespread and commonly collected Neotropical species.

Schradera has several distinctive morphological features, some of which were studied in detail by Puff et al. (1993, 1998). A notable feature is the climbing habit of most of the species, which have two heteromorphic developmental phases. Juvenile Schradera climbers are slender with relatively small leaves that are appressed to their substrate, and use their numerous adventitious roots to attach their stems to this supporting substrate. These resemble juvenile plants of some species of Philodendron Schott (Araceae) and Marcgraviaceae and are sometimes confused with those. Juvenile Schradera climbers of different species are apparently similar morphologically and rarely documented. The climbing species are at least sometimes terrestrial (S. exotica (J. F. Gmel.) Standl., Puerto Rico, Taylor, pers. obs.) but are reported to be epiphytic on numerous specimen labels; whether those plants are terrestrials that lost connection with the ground, actual epiphytes, or misidentified stems in dense tangles needs further field study. Plants such as Philodendron and Monstera Adans., which germinate as terrestrials, climb a supporting tree or shrub, and later break their connection to the ground, are referred to in the ecological literature as "secondary hemiepiphytes" (Kress, 1986; Putz \& Holbrook, 1986), and perhaps that term should apply to Schradera as well; however, Zotz (2013) makes the case that "secondary hemiepiphyte" is misleading and suggests use of the alternative "nomadic vine." When the juvenile stem of a climbing Schradera reaches an exposed area, such as a light gap or the forest canopy, it produces the reproductive stems. These are markedly different morphologically: leathery, spreading or hanging free of their support, without adventitious roots, with larger leaves, and bearing inflorescences and infructescences. These are the stems that are documented in herbarium specimens and described in taxonomic treatments. Schradera has been characterized until now as a climbing genus, but one new species described here, S. condorica C. M. Taylor \& D. A. Neill, is well documented as a free-standing tree that is at least sometimes terrestrial. Another new species described here, S. morindoides C. M. Taylor, is also documented to grow facultatively as a terrestrial shrub or small tree. These trees grow on a wet oligotrophic sandstone, however, so the plants may be rooted on the ground but physiologically growing as epiphytes; such a facultative habit is found in some other epiphytic Rubiaceae (e.g., Cosmibuena Ruiz \& Pav.; Taylor, 1992).

Other distinctive features of Schradera include both vegetative and reproductive structures. The stipules of this genus are variously interpetiolar or shortly fused into a tube, and their flattened, erect form on the stem apex is distinctive on vegetative growth and allows recognition of this genus even when sterile. The inflorescences are distinctive in the tubular to patelliform involucre that encloses the flower heads (or solitary flowers in a few species), which is truncate, spreading, and persists through fruiting; this developed truncate involucre is unique to Schradera in the Neotropics. The inflorescences are also unusual in arrangement, with most Schradera species having five to three dozen flowers grouped together in a hemispherical to subglobose head. The individual flowers are free or sometimes partially to fully fused by their ovaries. This inflorescence arrangement is similar in the Neotropics to that of Morinda L. and Appunia Hook. f., which have similar corollas as well but differ in their short triangular stipules, reduced involucres, and fruits with two to four pyrenes.

The inflorescences of Schradera are generally produced terminally on a single peduncle at the apex of a 
regularly developed stem, or sometimes on two or more peduncles at the stem apex. The presence of three main axes in a terminal inflorescence is a frequent arrangement in Rubiaceae and arises from the development of inflorescences also from the axillary buds that subtend the terminal bud. The production of four to six terminal peduncles in Schradera is common (Puff et al., 1993), but this arrangement is not well understood and was not studied anatomically by Puff et al. The structure supporting a flower head is here referred to as a peduncle following Steyermark (1974), Puff et al. (1993), and Taylor (2003). The involucre is formed by an outgrowth of the (reduced) inflorescence axis and is not formed even in part by fused bracts (Puff et al., 1993). The flowers are grouped into a head or subcapitate group due to reduction of the pedicels and inflorescence axes. A few Schradera species produce flowers that are borne singly, with each enclosed by an involucre and borne on its own peduncle. These single-flowered inflorescences are regarded in this genus as reduced inflorescence heads (Puff et al., 1993). A few other species of Schradera have inflorescences borne on relatively shortened, leaf-bearing lateral stems that arise from longer, sometimes leafless main stems, but are clearly terminal here. A few other Schradera species have inflorescences that are each borne on a single peduncle in the leaf axils of the main stems, with the peduncles borne directly from the stem or sometimes with a leafless articulation at the base. These inflorescences, including their supporting structure, are here interpreted as brachyblasts, or reduced lateral stems, that are similar in form to the relatively shortened lateral stems with terminal peduncles. This brachyblast arrangement is called axillary for convenience, but the inflorescences of Schradera are "essentially terminal" (Puff et al., 1993).

The corollas of Schradera are white, and in at least some species they are strongly fragrant at night and apparently nocturnal (Taylor, pers. obs.). After anthesis the corolla usually becomes yellowed, and it is most often observed the day after anthesis in this condition. The corolla lobes are so thickly fleshy that they are often triangular in cross section, and characteristically their tips are prolonged past their junction with the other lobes into a fleshy conical tip or horn. The lobes also sometimes have a short, galeate, adaxial projection about $0.1-0.3 \mathrm{~mm}$ long in their upper part. These projections apparently meet in bud to cover or close the internal corolla space. The ovary is basically 2locular in Schradera, but in some species it is 3- or 4-locular (Steyermark, 1963; Puff et al., 1998); the stability (or variation) of this feature within species has not been well surveyed. No mature fruit color has been noted for any species of Schradera, and the fruits may be green at maturity or the ripe fruits may be quickly removed by frugivores and as-yet unobserved.
1. Schradera cernua C. M. Taylor, sp. nov. TYPE: Colombia. Nariño: mpio. Barbacoas, Km. 2 trayecto Junín-Barbacoas, 1150 m, 14 Apr. 1989, B. R. Ramírez P. 1335 (holotype, PSO-019719 image!; isotype, MO-04911138!). Figure 3A.

Diagnosis. Schradera cernua C. M. Taylor is distinguished from other species of Schradera by the combination of its relatively small, elliptic to suborbicular leaves, well-developed flexuous peduncles, and solitary flower heads with short involucres and only three or four flowers.

Scandent shrubs with well-developed, leafless main branches and regularly developed but shorter, sparsely branched lateral stems that bear the leaves and inflorescences; stems glabrous, quadrangular becoming terete with age. Leaves opposite; blade elliptic to suborbicular, $1.5-2.5 \times 0.8-2 \mathrm{~cm}$, at base cuneate, at apex obtuse then shortly acuminate with deltate tip 1-2 mm, drying chartaceous with margins thinly revolute, on both surfaces glabrous and shiny; secondary veins 4 to 6 pairs, without intersecondary veins, adaxially venation plane, abaxially venation plane or costa prominent; petiole 2-4 mm, glabrous; stipules caducous, not seen. Inflorescences terminal, pedunculate, glabrous; peduncle solitary, 1.2-5.5 cm; head 0.6-1.2 cm diam. (not including corollas), hemispherical, 3- or 4-flowered; involucre cupuliform to patelliform, 3-4 mm, truncate. Flowers sessile; hypanthium obconic, ca. $3 \mathrm{~mm}$, glabrous; calyx limb glabrous, $2-4 \mathrm{~mm}$, truncate, thintextured; corolla salverform, white, externally glabrous, internally not seen, tube ca. $9 \mathrm{~mm}$, ca. $1.5 \mathrm{~mm}$ diam. near middle, lobes 5 , narrowly triangular, ca. $3 \mathrm{~mm}$, adaxially with galeate projection, at tip acute and with fleshy conical appendage ca. $1.2 \mathrm{~mm}$; anthers not seen; stigmas ca. $2 \mathrm{~mm}$, positioned in corolla throat on style ca. $8 \mathrm{~mm}$. Infructescences similar to inflorescences. Immature fruits subglobose to oblate, $5 \times 5-5.5 \mathrm{~mm}$, glabrous; seeds angled to flattened, suborbicular to irregularly angled, margins entire to apiculate.

Habitat, distribution, and phenology. This species is found in wet forest at 1150-1185 m on the Pacific slopes of southwestern Colombia; it has been collected in flower in April and in fruit in October.

Notes. Schradera cernua is characterized by the combination of its relatively small, elliptic to suborbicular leaves, solitary flexuous peduncles, rather small flower heads that appear to be nodding in life, and medium-sized flowers and fruits. The specific epithet refers to the nodding flower heads. The label data are not adequate to determine if this species is epiphytic or terrestrial, or a low shrub or high climbing. The area where this new species was collected has very high rainfall, high floristic diversity, and a number of endemic plant species but is not well explored (Taylor, 

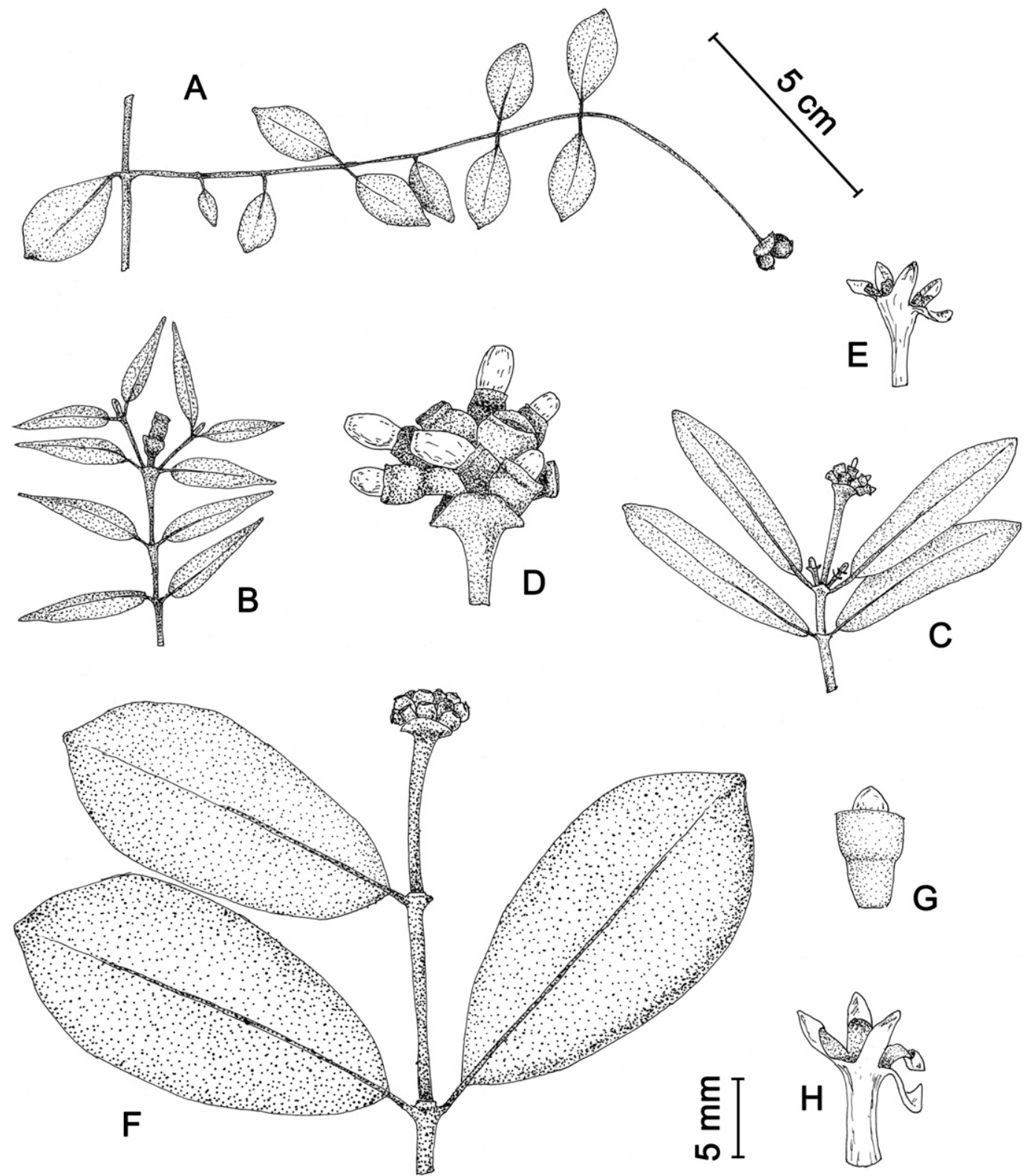

Figure 3. - A. Schradera cernua C. M. Taylor, fruiting branch. -B. Schradera francoae C. M. Taylor, branch with immature fruit. C-E. Schradera morindoides C. M. Taylor. - C. Flowering branch. - D. Inflorescence with six flowers in bud and three flowers from which corollas have fallen. - E. Corolla at anthesis. F-H. Schradera condorica C. M. Taylor \& D. A. Neill. -F. Branch with young infructescence. - G. Flower bud. - H. Corolla at anthesis. A based on J. Betancur et al. 7440. B based on Franco et al. 1424. C, D based on H. Beltrán \& R. Foster 1186. E based on D. Wolff 155. F based on J. Homeier 5211. G, H based on W. Quizhpe, F. Tello, B. Medina, W. Zeas \& L. Andrade 3132. A, B, C, F to 5-cm scale; D, E, G, H to 5-mm scale.

2017b), so whether this species is rare or restricted in range is also difficult to assess.

Schradera cernua is only known from two collections, but it is clearly distinct from the other Neotropical species of this genus. The most similar Andean species is $S$. revoluta Standl., which can be separated by its elliptic to narrowly elliptic leaves, stout peduncles
1-1.5 cm long, larger flowering heads with five to eight flowers, larger involucres 7-8 mm long, and larger corolla lobes 6-7 mm long (including their apical appendages, which are ca. $4 \mathrm{~mm}$ long).

Paratypes. COLOMBIA. Nariño: mpio. Barbacoas, correg. Junín, carretera hacia Barbacoas poco después de Junín, J. Betancur et al. 7440 (COL n.v., MO). 
2. Schradera condorica C. M. Taylor \& D. A. Neill, sp. nov. TYPE: Ecuador. Zamora-Chinchipe: cantón Yantzaza, región Cordillera del Cóndor, cuenca del río Machinaza, campamento Las Peñas, Parcela 1, $3^{\circ} 46^{\prime} \mathrm{S}, 78^{\circ} 29^{\prime} \mathrm{W}-3^{\circ} 45^{\prime} \mathrm{S}, 78^{\circ} 30^{\prime} \mathrm{W}, 1400-1840 \mathrm{~m}$, 17 Oct. 2008, W. Quizhpe, F. Tello, B. Medina, W. Zeas \& L. Andrade 3132 (holotype, MO-6848668!; isotypes, ECUAMZ!, MO-6848667!). Figure 3F-H.

Diagnosis. Schradera condorica C. M. Taylor \& D. A. Neill is distinguished from S. campii Standl. ex Steyerm. by its coriaceous leaves that are obtuse to rounded at their tips and smaller corollas, and from S. morindoides C. M. Taylor by its larger leaves and flower heads.

Climbing to erect shrubs and small trees to $15 \mathrm{~m}$, with similarly well-developed main and lateral branches; stems glabrous, when young flattened, becoming subterete or weakly quadrangular. Leaves opposite; blade obovate to oblong-obovate, $(4-) 4.5-9.5 \times(1.5-)$ $3-5.2 \mathrm{~cm}$, at base cuneate to rounded or subtruncate, at apex obtuse to rounded, drying coriaceous with margins weakly revolute, on both surfaces glabrous, adaxially often shiny; secondary veins 8 to 10 pairs, with 1(2) well-developed intersecondary veins present between pairs of secondary veins, adaxially costa plane to sulcate or prominent and remaining venation plane, abaxially costa prominent and secondary and intersecondary veins plane to prominulous; petiole (0.5-) $0.8-1.4 \mathrm{~cm}$, glabrous; stipules caducous, glabrous, obovate, $17-25 \mathrm{~mm}$, fused for $3 / 4$ or more of their length, rounded at tips. Inflorescences terminal, pedunculate, glabrous; peduncle solitary, $2.3-4 \mathrm{~cm}$; head subglobose, $1.5-2 \mathrm{~cm}$ diam. (not including corollas), ca. 20- to 40-flowered; involucre patelliform to weakly funnelform, 5-6 mm, truncate. Flowers sessile; hypanthium portion obconic, ca. $3 \mathrm{~mm}$, glabrous; calyx limb glabrous, 3-4 mm, truncate, thickly fleshy and flattened on top, closely set to calyx limbs of adjacent flowers to form a continuous fleshy surface on flower head; corolla salverform, white, externally glabrous, internally densely villous in upper half of tube, tube ca. $8 \mathrm{~mm}$, ca. $1.5 \mathrm{~mm}$ diam. near middle, lobes 5 , narrowly triangular, ca. $3 \mathrm{~mm}$, adaxially with galeate projection, at tip acute and with fleshy conical appendage ca. $1 \mathrm{~mm}$; anthers ca. $3 \mathrm{~mm}$, included, positioned just below top of corolla tube; stigmas ca. $1 \mathrm{~mm}$, exserted on retrorsehispidulous style. Infructescences to $3.5 \mathrm{~cm}$ diam., with involucre to $10 \mathrm{~mm}$. Fruits obovoid to obconic-angled, 5-6 × 5-6 mm, glabrous; seeds 1-1.5 mm, flattened, suborbicular to ellipsoid, margins entire.

Habitat, distribution, and phenology. This species is found in wet forest, exclusively, as far as known, on oligotrophic sandstone substrates, at $1312-2100 \mathrm{~m}$ in the Cordillera del Cóndor region in southern Ecuador; it has been collected in flower in March, April, June, July,
October, and December, and with well-developed fruits in March, September, and October.

Notes. Schradera condorica is characterized by its shrub to small tree habit; thick-textured, medium-sized, apically obtuse to rounded leaf blades; subglobose flower heads; unusual fleshy and flat-topped calyx limbs; and medium-sized corollas. The fleshy calyx limbs of the flowers are so closely set that the entire flowering head appears to form a single fleshy structure, similarly to the aggregate fruits of Morinda. The pressure of the flowers expanding circumferentially against each other produces an irregularly angled form in their calyces, in a packing arrangement generally similar to a honeycomb. The individual flowers of S. condorica are free, however, and the ovaries and calyx limbs separate from each other later as the fruits enlarge. Similar fleshy calyx limbs are found in some other Ecuadorian Schradera species, in particular S. campii and S. morindoides. Schradera condorica is found in the Cordillera del Cóndor region, and the epithet refers to this area.

Schradera condorica has been documented in plot inventories as a tree (that is, with a trunk diameter of $10 \mathrm{~cm}$ or greater) and reported on most specimens to grow to $10-15 \mathrm{~m}$ tall. Its inclusion in these inventories suggests it is terrestrial, but epiphytic shrubs are sometimes also included in inventories of dense, tangled vegetation. As discussed in more detail in the introduction, this is the first clear documentation of a welldeveloped tree habit in Schradera.

One specimen from Morona-Santiago (Pabón et al. 318 ) is provisionally included here, but differs from the plants of other areas in its relatively smaller leaves with shorter petioles. This specimen lacks flowers but otherwise agrees with Schradera condorica, including in its habitat at $2000 \mathrm{~m}$ in dwarf forest on quartzite in the Cordillera del Cóndor. The overall size range of its leaf blades overlaps with that of plants from other regions, but its smallest leaf and petiole measurements are distinct and are included in the description above in parentheses.

Schradera condorica is similar to $S$. campii of northern through central Ecuador. Schradera campii can be separated by its elliptic leaves with acute to acuminate tips and the venation usually prominulous on both surfaces, along with its larger corollas, with tubes 9.5-13 mm long and lobes 6-12 mm long. Schradera condorica is also similar to $S$. morindoides; see the discussion of that species below for their distinctions.

Paratypes. ECUADOR. Morona-Santiago: cantón Gualaquiza, cresta de la Cordillera del Cóndor, arriba del valle del río Quimi, G. Pabón et al. 318 (MO, QCNE), M. Cuascota et al. 279 (QCNE). Zamora-Chinchipe: tepui-like mtn. crest close to village of Las Orquídeas (Río Nangaritza), J. Homeier 5211 (GOET n.v., MO, QCA n.v.); cantón El Pangui, Cordillera del Cóndor, upper watershed of Río Wawaime (tributary of Río 
Quimi), vic. of EcuaCorriente copper mine development, T. B. Croat et al. 96583 (MO, QCNE), C. Morales \& D. Reyes 1966 (LOJA n.v., MO, WU n.v.), D. Neill \& W. Quizhpe 14972 (MO, QCNE), 14999 (MO, QCNE, WU n.v.), 15257 (ECUAMZ, MO), D. Neill et al. 15887 (LOJA n.v., MO, QCNE, WU n.v.), ca. $1 \mathrm{~km} \mathrm{~S}$ of Cóndor Mirador military post, on Ecuador-Peru border, $D$. Neill et al. 14461 (MO, QCNE), vic. of mining camp at Río Tundaime, along trail from El Cóndor military base, $H$. van der Werff et al. 18964 (MO, QCNE, WU n.v.), W. Ramírez 73 (QCNE), T. Montenegro 184 (QCNE); cantón Palanda, parroquia San Francisco de Vergel, Cordillera del Cóndor, cuenca alta del río Vergel, Pica de Sol Naciente, W. Quizhpe et al. 1069 (LOJA n.v., MO, QCNE); cantón Yantzaza, Cordillera del Cóndor, $1 \mathrm{~km}$ N of Río Machinaza at Las Peñas, $D$. Neill \& W. Quizhpe 16276 (ECUAMZ, LOJA n.v., MO, QCNE, WU n.v.), Río Machinaza watershed E of Los Encuentros, $D$. Neill \& C. Kajekai 16984 (ECUAMZ, MO, QCNE), carretera desde Los Encuentros hacia el Cerro Machinaza, sendero a Las Peñas, W. Quizhpe 1614 (LOJA n.v., MO, QCNE, WU n.v.), Parcela 1, W. Quizhpe et al. 3134 (ECUAMZ, MO), Parcela 6, W. Quizphe et al. 3190 (ECUAMZ, MO).

3. Schradera francoae C. M. Taylor, sp. nov. TYPE: Colombia. Chocó: mpio. San José del Palmar, vereda El Tabor, finca El Tabor, 1650 m, 17 Jan. 1983, P. Franco, O. Rangel, A. Cleef \& S. Salamanca 1424 (holotype, COL-419841 image!; isotypes, MO4236611!, MO-5203895!). Figure 3B.

Diagnosis. Schraderafrancoae C. M. Taylor is distinguished from S. subandina K. Krause by its smaller leaves, with secondary venation not evident, and terminal inflorescences.

Climbing shrubs with similarly well-developed main and lateral branches; stems glabrous, subterete to quadrangular. Leaves opposite; blade lanceolate, 1.5-3.2 $\times$ $0.3-1 \mathrm{~cm}$, at base obtuse to rounded, at apex narrowly acute and often falcate, drying coriaceous with margins revolute, on both surfaces glabrous; secondary and other venation not evident, adaxially costa prominulous and remaining venation plane, abaxially costa prominent and remaining venation plane; petiole 1-6 mm, glabrous; stipules caducous, glabrous, narrowly ligulate, 4-5 mm, fused for $1 / 2-2 / 3$ and sometimes tardily splitting below this, rounded at tips. Inflorescences not seen. Flowers not seen. Infructescences terminal, shortly pedunculate, glabrous; peduncle solitary, 1-3 mm; head 1-flowered; involucre cupuliform, $2-5 \mathrm{~mm}$, truncate. Fruits subglobose, ca. $6 \mathrm{~mm}$ diam., glabrous, with the persistent calyx 5-6 mm, truncate, thin-textured; seeds not seen.

Habitat, distribution, and phenology. This species is found in wet forest at ca. $1650 \mathrm{~m}$, in the Cordillera Occidental of western Colombia; it has been collected in fruit in January.

Notes. Schradera francoae is unusual in this genus for its relatively small leaves and consistently terminal inflorescences that each have only one flower. Although this species is only known from one collection, it is clearly distinct. This collection was made by the distinguished and, sadly, late Colombian botanist Dr. María del Pilar Franco Rosselli (1950-2000), and the epithet honors her. The label data are not adequate to determine if this species is epiphytic or not, or a low- or high-climbing shrub.

Only one other Neotropical species, Schradera subandina, has inflorescences with solitary flowers. Schradera subandina can be separated by its larger leaf blades, 4-18 × 1.4-8 cm, that are obtuse to deltate at the apex and have eight to 12 well-marked pairs of secondary veins, axillary inflorescences that are borne along the main stems on reduced lateral stems, and often longer calyx limbs 4-8 $\mathrm{mm}$. Schradera subandina is also geographically separated, in central Ecuador through northern Bolivia.

4. Schradera morindoides C. M. Taylor, sp. nov. TYPE: Ecuador. Zamora-Chinchipe: area of Estación Científica San Francisco, ca. $30 \mathrm{~km}$ from city of Loja at rd. to Zamora, $3^{\circ} 58^{\prime} 18^{\prime \prime} \mathrm{S}, 79^{\circ} 04^{\prime} 44^{\prime \prime} \mathrm{W}, 2430 \mathrm{~m}$, 11 Oct. 2001, D. Wolff 155 (holotype, MO-5607860!; isotype, UBT n.v.). Figure 3C-E.

Diagnosis. Schradera morindoides C. M. Taylor is distinguished from S. condorica C. M. Taylor \& D. A. Neill by its smaller leaves and smaller corollas.

Climbing shrubs or small trees to $4 \mathrm{~m}$ tall, with similarly well-developed main and lateral branches; stems glabrous, quadrangular sometimes becoming subterete. Leaves opposite; blade narrowly elliptic to oblanceolate or lanceolate, $2-5.8 \times 0.7-2.3 \mathrm{~cm}$, at base acute to obtuse, at apex acute to obtuse or rounded, drying coriaceous with margins thinly revolute, on both surfaces glabrous, adaxially often shiny; secondary veins 8 to 11 pairs, with a few short intersecondary veins sometimes present on some leaves, adaxially costa plane to sulcate and remaining venation plane and not visible, abaxially costa prominent, secondary veins plane to prominulous, and remaining venation plane and not evident; petiole $3-5 \mathrm{~mm}$, glabrous; stipules caducous, glabrous, oblanceolate, 9-19 mm, fused for ca. 3/4 of their length, rounded at tips. Inflorescences terminal, pedunculate, glabrous; peduncle solitary, 0.6-2 cm; heads subglobose, 0.8-1 cm diam. (not including corollas), 15- to 25-flowered; involucre patelliform, 2.5-3 mm, truncate. Flowers sessile; hypanthium portion obconic, ca. $2 \mathrm{~mm}$, glabrous; calyx limb glabrous, 2-3 mm, truncate, thickly fleshy and flattened on top, closely set so calyx limbs of adjacent flowers form a continuous fleshy surface on flower head; corolla salverform, white, externally glabrous, internally villosulous in throat, tube 4-6 mm, ca. $1.2 \mathrm{~mm}$ diam. near middle, lobes 5, narrowly triangular, 2-2.5 mm, adaxially with short galeate projection, at tip acute to obtuse and with fleshy conical appendage ca. $1 \mathrm{~mm}$; anthers ca. $1.5 \mathrm{~mm}$, partially exserted; stigmas ca. $1 \mathrm{~mm}$, exserted 
on hispidulous style. Infructescences to $1.5 \mathrm{~cm}$ diam., with involucre to $4 \mathrm{~mm}$. Fruits obovoid to obconicangled, ca. $5 \times 5 \mathrm{~mm}$, glabrous; seeds ca. $1 \mathrm{~mm}$, flattened, suborbicular to ellipsoid or angled, margins entire.

Habitat, distribution, and phenology. This species is found in wet, tall to dwarfed forest at $1100-2800 \mathrm{~m}$, in the Río Zamora drainage, the Cordillera de Cutucú, the Cordillera de Huaracayo, and the Cordillera del Cóndor in southern Ecuador and northern Peru; in the Cordillera del Cóndor it occurs on oligotrophic sandstone substrate (mostly at higher elevations than Schradera condorica) and in the eastern slopes of the Andes, on metamorphic schist substrate. It has been collected in flower in March, April, June, July, and October through December, and in fruit in March and July.

Notes. Schradera morindoides is characterized by its leathery, relatively small, relatively narrow leaves, somewhat small flower heads borne on developed peduncles, unusual fleshy calyx limbs, and relatively small corollas. The fleshy calyx limbs are similar to those described for $S$. condorica, previously here, and appear superficially to be fused to each other but are free. The species epithet refers to the similarity of these flower heads to those of Morinda morindoides (Baker) Milne-Redh., an African liana with fleshy subglobose fruits in which ovaries of the flowers are actually fused to each other. The label data regarding habit are not all in agreement with each other; the available data describe this species variously as an epiphytic shrub, a hemiepiphyte, a liana, a scandent or terrestrial shrub, or a small tree.

Schradera morindoides is similar to $S$. campii, which can be separated by its elliptic leaves with acute to usually acuminate tips and the venation usually prominulous on both surfaces, along with its larger corollas, with tubes 9.5-13 $\mathrm{mm}$ long and lobes 6-12 mm long. Schradera morindoides is also similar to $S$. condorica, which differs in its obovate to oblong-ovate, usually larger leaf blades, 4-9.5 × 1.5-5.2 cm, larger corollas with tubes ca. $8 \mathrm{~mm}$ long and lobes ca. $3 \mathrm{~mm}$ long (including the apical horns, which are ca. $1 \mathrm{~mm}$ ), and usually larger fruiting heads $1.5-3.5 \mathrm{~cm}$ in diameter. Schradera morindoides is also similar to $S$. revoluta, which differs in its leaf blades that are acute to acuminate at the tips, longer calyx limbs ca. $6 \mathrm{~mm}$, and larger corollas with tubes ca. $10 \mathrm{~mm}$ long.

Paratypes. ECUADOR. Loja: cantón Loja, carretera Loja-Zamora, ca. al cumbre, D. Rubio et al. 2253 (MO, QCNE). Morona-Santiago: cantón Morona, Cordillera de Cutucú, centro Shuar Angel Roubi, F. Nicolalde et al. 1347 (MO, QCNE); cantón Gualaquiza, Cordillera del Cóndor, 15 km E Gualaquiza, campamento Achupalla, A. Gentry 80289 (MO, QCNE); cantón Limón-Indanza, Cordillera del Cóndor,
10-15 km SSE of comunidad Warints, trail to crest, J. L. Clark \& L. Jost 6986 (MO, QCNE, US n.v.); centro Shuar Warints, cumbre del Cerro Paatin Naint, G. Toasa 8974 (MO, QCNE n.v.), Cerro Maka Naint, $6 \mathrm{~km}$ al SW del centro Shuar, $G$. Tsuink et al. 14 (MO, QCNE n.v., WU n.v.), recorrido Cerro Chankinians-Cordillera del Cóndor, G. Tsuink et al. 34 (MO, QCNE); Cordillera de Huaracayo, E of Cordillera del Cóndor \& Río Coangos, Cerro Ijiach Naint, E of Shuar village of Tikimints, P. Berry \& D. Neill 7670 (MO, QCNE, WU n.v.), $P$. Berry \& D. Neill 7654 (MO), D. Neill et al. 13073 (MO, QCNE). Zamora-Chinchipe: cantón El Pangui, Cordillera del Cóndor, $1 \mathrm{~km}$ al $\mathrm{N}$ del destacamento militar "Cóndor Mirador," $E$. Rodríguez et al. 2628 (HUT n.v., LOJA n.v., MO, QCNE, WU n.v.), Contrafuerte Wawayme, Río, J. Cerón 1719 (QCNE), Wawaime watershed, tributary of Río Quimi, rd. from EcuaCorrientes camp to mine site, H. van der Werff \& W. Quizhpe 21604 (MO, QCNE, WU n.v.); cantón Nangaritza, Cordillera del Cóndor, Reserva Biológica Cerro Plateado, D. Neill et al. 17512 (ECUAMZ); cantón Yantzaza, Cordillera del Cóndor, Machinaza plateau summit area, end of trail from upper Paquisha military post at Ecuador-Peru border, D. Neill \& W. Quizhpe 16166 (ECUAMZ, MO, QCNE, WU n.v.), comunidad Río Blanco, J. Cerón et al. 1835 (QCNE); cantón Zamora, new rd. Loja-Zamora, $2 \mathrm{~km}$ E of pass, C. Persson 525 (GB, MO, QCA n.v., QCNE), area of Estación Científica San Francisco, ca. $30 \mathrm{~km}$ rd. Loja-Zamora, A. Freire F. \& A. Cedeño 3109 (MO), J. Madsen et al. 7103 (AAU n.v., QCNE), F. Werner 093 (MO, UBT n.v.). PERU. Amazonas: prov. Condorcanqui, Cordillera del Cóndor, Cerro Machinaza, cabeceras río Comainas, tributario río Cenepa, arriba Puesto de Vigilancia Alfonso Ugarte, H. Beltrán \& R. Foster 1186 (F, MO, USM n.v.). Cajamarca: prov. San Ignacio, San José de Lourdes, área de Cerro Picorana, J. Campos \& L. Zurita 5866 (MO, WU n.v.), 5946 (MO, WU n.v.), C. Díaz et al. 10302 (MO, WU n.v.), C. Díaz \& S. Fernández 10216 (MO, WU n.v.), trocha límite con La Unión, C. Díaz \& A. Torres 7804 (MO, WU n.v.); distr. Huarango, entre El Romerillo y Nuevo Mundo, Cordillera El Romerillo-Salsipuedes-El Mirador, E. Rodríguez \& J. Campos 1827 (MO), El Romerillo, E. Rodríguez et al. 2820 (HUT n.v., QCNE), Poblado Selva Andina, J. Perea et al. 3625 (QCNE, USM n.v.).

Acknowledgments. Many sincere thanks are due to our colleagues Rosa Ortiz, Sabine Will, Claes Persson, Suzanne Hirth, Johan Rova, Nancy Hensold, and especially Robin Foster and Roy E. Gereau for help and encouragement with this work; to COL, F, HUA, PSO, QCNE, and UBT for access to specimens and information and especially in this regard to our colleagues Marcia Peñafiel Cevallos, Felipe Cardona, Aida Elena Baca Gamboa, Carlos Parra, Katya Romoleroux, and Sigrid Liede-Schumann; to the Rapid Inventories program of the Field Museum for support for C. M. T.'s travel to that institution; to the John D. and Catherine T. MacArthur Foundation for support in the $1990 \mathrm{~s}$ for botanical exploration in northeastern Peru, which produced materials we are still analyzing; to the William Froelich Foundation for significant financial support and J. S. Miller for general support to C. M. T. that facilitated this work; and to the National Science Foundation (DBI-1559962) for support for M. C. C. through the Missouri Botanical Garden's Research 
Experiences for Undergraduates (REU) program, and to Wendy Applequist, Mónica Carlsen, Peter Hoch, and James D. Ackerman for facilitating her participation in that program.

\section{Literature Cited}

Andersson, L. \& J. H. E. Rova. 2004. Rubiaceae (Part 4), Tribe 9. Hippotideae. Pp. 1-44 in G. W. Harling \& L. Andersson (editors), Flora of Ecuador, Vol. 74. University of Göteborg, Göteborg.

Calderón Cruz, M. \& C. M. Taylor. 2018. Two new species of Hippotis (Rubiaceae) from Ecuador and Peru. Novon 26: 143-149, doi: 10.3417/2018062.

Delprete, P. G. \& R. Cortés-Ballén. 2016. Rubiaceae. Pp. 2252-2343 in R. Bernal González, S. R. Gradstein \& M. Celis (editors), Catálogo de Plantas y Líquenes de Colombia, Vol. 2. Universidad Nacional de Colombia (Sede Bogotá), Instituto de Ciencias Naturales, Bogotá.

Kainulainen, K., C. H. Persson, T. Eriksson \& B. Bremer. 2010. Molecular systematics and morphological character evolution of the Condamineeae (Rubiaceae). Amer. J. Bot. 97: 1961-1981.

Kress, W. J. 1986. The systematic distribution of vascular epiphytes: An update. Selbyana 9: 2-22.

Lawrence, G. H. M. 1951. Taxonomy of Vascular Plants. The MacMillan Company, New York.

Lorence, D. H., C. M. Taylor, C. D. Adams, L. Andersson, W. C. Burger, P. G. Delprete, K. Es, et al. 2012. Rubiaceae. Pp. 1-288 in G. Davidse, M. Sousa S., S. Knapp \& F. Chiang (editors), Flora Mesoamericana, Vol. 4(2): Rubiaceae a Verbenaceae. Universidad Nacional Autónoma de México, México, D. F.; Missouri Botanical Garden, St. Louis; The Natural History Museum, London.

Puff, C., L. Andersson, U. Rohrhofer \& A. Igersheim. 1993. The tribe Schradereae (Rubiaceae) reexamined. Bot. Jahrb. Syst. 114: 449-479.

Puff, C., J. Greimler \& R. Buchner. 1998. Revision of Schradera (Rubiaceae-Schradereae). Blumea 43: 287-335.

Putz, F. E. \& N. M. Holbrook. 1986. Notes on the natural history of epiphytes. Selbyana 9: 61-69.
Rova, J. H. E. \& L. Andersson. 1995. A reevaluation of the tribes Hippotideae and Tammsieae (Rubiaceae). Nordic J. Bot. 15: 269-284.

Steyermark, J. A. 1963. Rubiaceae. Pp. 186-278 in B. Maguire \& collaborators, The Botany of the Guayana Highland-Part V. Mem. New York Bot. Gard. 10.

Steyermark, J. A. 1965. Género Hippotis. Acta Bot. Venez. 1: 85-102.

Steyermark, J. A. 1974. Rubiaceae. Pp. 7-2070 in T. Lasser (editor), Flora de Venezuela, Vol. 9. Fondo Editorial Acta Científica Venezolana, Caracas.

Taylor, C. M. 1992. Revision of Cosmibuena (Rubiaceae). Ann. Missouri Bot. Gard. 79: 886-900.

Taylor, C. M. 1997. Rubiaceae. Pp. 602-637 in R. Vásquez Martínez, Flórula de las Reservas Biológicas de Iquitos, Perú: Allpahuayo-Mishana, Explornapo Camp, Explorama Lodge. Monogr. Syst. Bot. Missouri Bot. Gard. 63.

Taylor, C. M. 2002. Rubiacearum americanarum magna hama pars IX. New species and a new combination in Hippotis and Pentagonia (Hippotideae) from Central and western South America. Novon 12: 555-562.

Taylor, C. M. 2003. Rubiacearum americanarum magna hama pars XIII. A new species of Schradera (Schradereae) from Mesoamerica. Novon 13: 220-222.

Taylor, C. M. 2017a. Another taxonomic review of the Neotropical genus Joosia (Rubiaceae, Cinchoneae). Novon 25: 214-237.

Taylor, C. M. 2017b. Rubiacearum americanarum magna hama pars XXXVII: The new group Palicourea sect. Chocoanae of the Chocó biogeographic region, with two new species (Palicoureeae). Novon 25: 322-342.

Taylor, C. M., J. A. Steyermark, P. G. Delprete, A. Vincentini, R. Cortés, D. C. Zappi, C. H. Persson, et al. 2004. Rubiaceae. Pp. 497-847 in J. A. Steyermark, P. E. Berry \& B. K. Holst (editors), Flora of the Venezuelan Guayana, Vol. 8. Missouri Botanical Garden Press, St. Louis.

Vásquez Martínez, R. 1997. Flórula de las Reservas Biológicas de Iquitos, Perú: Allpahuayo-Mishana, Explornapo Camp, Explorama Lodge. Monogr. Syst. Bot. Missouri Bot. Gard. 63: 1-1046.

Zotz, G. 2013. 'Hemiepiphyte': A confusing term and its history. Ann. Bot. 111: 1015-1020. 